\title{
Bacterioplankton community composition in 67 Finnish lakes differs according to trophic status
}

\author{
Eija Kolmonen ${ }^{1}$, Kaisa Haukka ${ }^{1,3}$, Anne Rantala-Ylinen ${ }^{1}$, \\ Pirjo Rajaniemi-Wacklin ${ }^{1,4}{ }^{4}$ Liisa Lepistö ${ }^{2}$, Kaarina Sivonen ${ }^{1, *}$ \\ ${ }^{1}$ University of Helsinki, Department of Food and Environmental Sciences, Division of Microbiology, Viikki Biocenter, \\ PO Box 56, 00014 Helsinki University, Finland \\ ${ }^{2}$ Finnish Environment Institute, PO Box 140, 00251 Helsinki, Finland \\ ${ }^{3}$ Present address: National Institute for Health and Welfare, PO Box 30, 00271 Helsinki, Finland \\ ${ }^{4}$ Present address: Finnish Red Cross Blood Service, Research and Development, Kivihaantie 7, 00310 Helsinki, Finland
}

\begin{abstract}
The bacterioplankton composition of 67 Finnish lakes was characterised by denaturing gradient gel electrophoresis (DGGE) of PCR-amplified 16S rRNA gene fragments, and subsequent sequence analyses of major fragments. The DGGE patterns grouped as a function of environmental characteristics describing the trophic status of the lakes, such as total phosphorus (TP), total nitrogen (TN), TN:TP, chlorophyll $a$, Secchi depth and water colour. Most sequences retrieved represented Verrucomicrobia, Actinobacteria and Cyanobacteria, while those representing Alpha- and Gammaproteobacteria, Chloroflexi and Acidobacteria were less frequent. The presence of several sequences could be linked to the trophic status of the lakes, while that of others was more common and thus unrelated to the trophic status. These results suggest that individual responses towards environmental factors may occur among the bacterioplankton at the level of phyla as well as phylotypes.
\end{abstract}

KEY WORDS: Bacterioplankton community composition · Lake trophic status · DGGE · Canonical correspondence analysis · CCA

\section{INTRODUCTION}

Bacterioplankton in freshwater ecosystems has a key role in nutrient cycling. Thus, detailed understanding of their distribution and the factors affecting bacterioplankton community composition are important. It has been suggested that relatively few groups of bacteria dominate freshwater systems and that these groups are widespread around the world (Zwart et al. 2002, Stepanauskas et al. 2003). According to previous studies, the most common freshwater bacteria belong to the divisions Proteobacteria, Actinobacteria, Cyanobacteria and Verrucomicrobia and to the CytophagaFlavobacterium-Bacteroides group (Zwart et al. 2002). In addition, it has been shown that lakes contain many bacterial groups that are distinct from those found in the oceans (Zwart et al. 2002).
The roles of the various factors governing bacterioplankton distribution are under debate. The influence of seasonality, such as water column mixing and thermal stratification, on bacterial community composition (BCC) is well established (Yannarell et al. 2003, Shade et al. 2007, 2008, Nelson 2009). Several studies have revealed a statistical relationship between BCC and temperature (Van der Gucht et al. 2001, Muylaert et al. 2002, Yannarell et al. 2003, Jardillier et al. 2004, Yannarell \& Triplett, 2004, 2005, Lindström et al. 2005, Kritzberg et al. 2006, Shade et al. 2007, 2008). In addition, BCC has been shown to vary along gradients of pH (Lindström 2000, Lindström \& Leskinen 2002, Stepanauskas et al. 2003, Lindström et al. 2005, Schauer et al. 2005, Yannarell \& Triplett 2005, Haukka et al. 2006), humic acid content (Haukka et al. 2005) and lake water retention time (Lindström et 
al. 2005). Muylaert et al. (2002) suggested that BCC was dependent on the dominant substrate source together with food web structure in 4 shallow eutrophic lakes. Grazing, biomass of microzooplankton and viral infections play an important role in controlling BCC (Lindström 2000, 2001, Hahn \& Höfle 2001, Jürgens \& Matz 2002, Kent et al. 2004, Van der Gucht et al. 2005). Jardillier et al. (2004) demonstrated that BCC depends on the combined effects of dominant substrate sources and selective predation by bacterial consumers. Nutrient availability, biomass of certain phytoplankton, lake productivity (concentration of chlorophyll a), water colour and transparency (Secchi depth) and dissolved organic carbon all appear to influence the BCC (Methé \& Zehr 1999, Lindström 2000, Yannarell \& Triplett 2004, 2005, Van der Gucht et al. 2005).

In the present study, we aimed to identify the features that best explained variation in BCC among 67 boreal lakes in Finland. Denaturing gradient gel electrophoresis (DGGE) of PCR-amplified 16S rRNA gene fragments and subsequent sequence analyses of specific fragments were used to characterise the bacterial community structure in water samples of these lakes. These data were then analysed by multivariate analysis in relation to physicochemical characteristics.

\section{MATERIALS AND METHODS}

Samples. Water samples included in this study originated from 67 lakes in southern and central Finland (see Table $\mathrm{S} 1$ in the supplement at www.int-res.com/ articles/suppl/a062p241_supp.pdf). From each lake, a composite sample from a depth of 0 to $2 \mathrm{~m}$ was collected from an open lake area. Samples were collected at the beginning of July or the middle of August with 1 exception, which was collected on 16 September 2002 (Lake Vitträsk, no. 71). For DNA extraction, an aliquot of 75 to $1000 \mathrm{ml}$ was filtered through a series of filters with pore sizes $10,5,1$ and $0.2 \mu \mathrm{m}$ as detailed by Rantala et al. (2006).

The physicochemical characteristics and cyanobacterial biomass of 55 and 50 lakes, respectively, have been analysed previously (Rantala et al. 2006), and these data were used in the statistical analyses. Cyanobacterial composition of the lakes was analysed by microscopy, and cell counts were converted to biovolumes using the cell volumes of the phytoplankton database of the Finnish Environment Institute (www.environment.fi) as described by Rantala et al. (2006). Nineteen of the lakes were oligotrophic (total

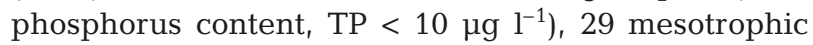
(TP: 10 to $34 \mu \mathrm{g} \mathrm{l}^{-1}$ ), 15 eutrophic (TP: 35 to $100 \mu \mathrm{g} \mathrm{l}^{-1}$ ) and 4 hypertrophic (TP $>100 \mu^{l^{-1}}$ ).
Nucleic acid extraction and PCR amplification. DNA was extracted from the cells on 10, 5, 1 and $0.2 \mu \mathrm{m}$ filters using a modified hot phenol method and purified by Nucleotrap PCR purification (BD Biosciences) and QuickStep PCR Purification (Edge BIOSystems) kits as detailed previously by Rantala et al. (2006). Primers F-968-GC and R-1401 targeting eubacterial 16S rRNA genes (Nübel et al. 1996) were used to amplify PCR products for DGGE. PCR reactions were performed in a volume of $16 \mu \mathrm{l}$ containing $1 \mu \mathrm{l}$ of template DNA, $200 \mathrm{nM}$ of primers F-968-GC and R-1401, $200 \mu \mathrm{M}$ dNTP solution, $1 \times$ PCR buffer, $1 \mathrm{M}$ betaine (Sigma), 0.3 U DyNAzyme $^{\mathrm{TM}}$ II DNA polymerase (Finnzymes) and sterile water up to $16 \mu$ l. The PCR programme consisted of a denaturing step at $94^{\circ} \mathrm{C}$ for $3 \mathrm{~min}, 35$ cycles at $94^{\circ} \mathrm{C}$ for $1 \mathrm{~min}, 51^{\circ} \mathrm{C}$ for $1 \mathrm{~min}$ and $72^{\circ} \mathrm{C}$ for $2 \mathrm{~min}$, and a final extension step at $72^{\circ} \mathrm{C}$ for $10 \mathrm{~min}$. The size and purity of the amplification products were checked on a $1.5 \%$ agarose gel. Two parallel PCR reactions from each sample were prepared and combined after amplification. The combined PCR products (approx. $80 \%$ of the reaction) were loaded into the DGGE gel.

DGGE. DGGE was performed on a Dcode ${ }^{\mathrm{TM}}$ Universal Mutation Detection System (Bio-Rad) using 6\% polyacrylamide and 35 to $55 \%$ formamide-urea gradients as previously described by Kolmonen et al. (2004). The samples were run in 4 gels and each contained 3 standard lines (see Fig. S1 in the supplement at www.int-res.com/articles/suppl/a062p241_ supp.pdf). Standards contained reamplified 16S rRNA gene fragments from a lake sample selected to cover the migration range of the bands. The standards with 6 band positions were applied for normalisation using Bionumerics software (Applied Maths BVBA, v 4.0). DNA bands were excised from the DGGE gels with a sterile scalpel and eluted from the gel slices using sterile water at $4^{\circ} \mathrm{C}$ overnight. These eluted products were reamplified and the PCR products were separated again in DGGE. In some cases, the band separation step was performed twice to ensure proper band separation. Several bands from different gels but the same position were sequenced as well as run again to ensure that each band position represented only 1 phylotype. From 46 band positions with sequenced bands, only 11 contained sequences from different phyla. Separated products from DGGE gels were reamplified with primers F-968 (without the GCclamp) and R-1401. PCR products were purified using Microcon PCR purification tubes (Millipore) and sequenced using the Big Dye cycle sequencing ready reaction kit (Applied Biosystems) according to the manufacturer's instructions. Sequencing reactions were analysed with the Applied Biosystems 310 genetic analyser. 
Sequence analysis. The partial 16S rRNA gene sequences derived from DGGE gels were analysed using NCBI-BLAST (Altschul et al. 1997) in order to identify the most similar sequences in the GenBank database (April 2009). Taxonomical classification of the bacterial sequences was confirmed with the Classifier analysis tool (Ribosomal Database Project II, Wang et al. 2007) (see Table 1). All the sequences were deposited in GenBank under accession numbers EU861397-EU861477, FJ970038.

Statistical data analysis. DGGE images were transferred to the BioNumerics software (Applied Maths BVBA, v 4.0) for normalisations of the electrophoresis patterns between the gels. The normalisation was based on standard samples run alongside the lake samples. The alignment was corrected by means of visual inspection of the gels. Automatic band search (minimum profiling 5\%) and band matching (position tolerance $1 \%$ ) were performed as implemented in Bionumerics. The band matching was corrected manually by means of visual inspection of the gels and comparison with sequencing data. The data matrix based on the presence or absence of DNA bands was used for statistical analyses.

Principal component analysis (PCA) was used to investigate the variation (presence/absence of the bands) in the DGGE profiles, by clustering of samples and taxa (bands) along axes on the basis of the banding patterns alone. PCA was performed with the CANOCO 4.52 software package (ter Braak \& Smilauer 2002).

In order to reveal relationships between the presence of bacterial groups and environmental factors, canonical correspondence analysis (CCA) in the CANOCO 4.52 software package (ter Braak \& Smilauer 2002) was used. Environmental variables, except $\mathrm{pH}$ and temperature, were $\log (x+1)$ transformed. The environmental variables used were: water temperature and colour, $\mathrm{pH}, \mathrm{TP}$, total nitrogen (TN), nitrate and nitrite nitrogen $\left(\mathrm{N}\left(\mathrm{NO}_{3}-\mathrm{NO}_{2}\right)\right)$, transparency as determined by Secchi depth, chlorophyll a ( $\mathrm{chl} a)$, ratio of dissolved inorganic nitrogen to dissolved inorganic phosphorus (DIN:DIP), TN:TP ratio, and latitude and longitude of the lake location.

CCA was applied to determine which environmental variables best explained patterns of similarity in DGGE profiles among bacterial communities in the lakes studied. Those band positions that occurred in fewer than 5 lakes were excluded from the analyses to avoid their too pronounced effect on the analysis. The environmental variables that contributed to the model significantly $(p<0.05)$ were included in the further analysis, using the manual selection of variables provided by CANOCO. This way the importance of individual variables can be determined (ter Braak \& Smilauer 2002).

\section{RESULTS}

\section{Lake characteristics}

The lakes sampled are situated in southern and central Finland between northern latitudes $60^{\circ} 10^{\prime}$ and $62^{\circ} 50^{\prime}$ and eastern longitudes $22^{\circ} 12^{\prime}$ and $28^{\circ} 11^{\prime}$. The size of the lakes varied from 0.02 to $863.3 \mathrm{~km}^{2}$. According to the TP content, the studied lakes ranged from oligotrophic to hypertrophic. $\mathrm{pH}$ values ranged from 5.8 to 10 . The $\mathrm{pH}$ of most of the lakes was neutral or alkaline, and 11 of the lakes were acidic. The lake temperature ranged from 15.4 to $22.8^{\circ} \mathrm{C}$, and the water colour from 8 to $160 \mathrm{mg}$ platinum (Pt) $\mathrm{l}^{-1}$. Of the lakes studied, 35 were clearwater lakes or the humus content was low $(<40 \mathrm{mg} \mathrm{Pt}$ $\mathrm{l}^{-1}$ ), and 32 were humic (humus content $>40 \mathrm{mg} \mathrm{Pt}^{-1}$ ). The chl a concentration varied from 1.2 to $130 \mathrm{mg} \mathrm{l}^{-1}$. In 6 lakes, cyanobacterial biomass ranged from 1 to $5.5 \mathrm{mg}$ $\mathrm{l}^{-1}$, and in all the other lakes cyanobacterial biomass was $<1 \mathrm{mg} \mathrm{l}^{-1}$. A higher biomass of cyanobacteria was detected in eutrophic and hypertrophic lakes than in oligoand mesotrophic lakes. Microcystis, Anabaena and Aphanizomenon spp. were the most common cyanobacteria detected in this study by means of microscopic counting. Detailed lake characteristics are provided as supplementary material (Table S1 in the supplement).

\section{Analysis of DGGE fingerprint patterns}

DGGE analysis retrieved highly variable patterns with 2 to 26 (average 17, SD 3.9; 1 lake with only 2 bands) fragments depending on the sample. Bands were detected in 61 different positions in the DGGE gels. The $16 \mathrm{~S}$ rRNA gene fragment sequences were obtained from 82/267 (30.7\%) DGGE bands, representing 46 band positions (75\%). The closest relatives (by BLAST analysis) for these sequences are shown in Table 1. The majority (80/82) of the sequences represented 6 bacterial phyla: Verrucomicrobia $(22$ sequences), Actinobacteria (19), Cyanobacteria (17), Proteobacteria (15), Chloroflexi (6), and Acidobacteria (1). Two sequences were of eukaryotic (chloroplast) origin.

Despite the variation in location, trophic status or water chemistry of the lakes, certain dominant band positions were common in all DGGE profiles. The most common (represented by FL22; Table 1) was observed in 62 of the total 67 lake samples analysed. The sequence of the band FL22 was similar to that of an uncultured alphaproteobacterium (clone PIB-1), previously detected in the Piburger See in Austria (Table 1). The second most common band position was observed in 54 of the 67 lakes and all the sequences (FL8, FL165, FL267; Table 1) derived from that band position were 
Table 1. Sequence similarities of the excised DGGE bands from 67 Finnish lakes, their taxonomic classification in the Ribosomal Database using the Classifier analysis tool and closest relatives in the GenBank database determined by BLAST (NCBI). BD: band designation; BD in databank: number of the band position found in all DGGE profiles is given in brackets

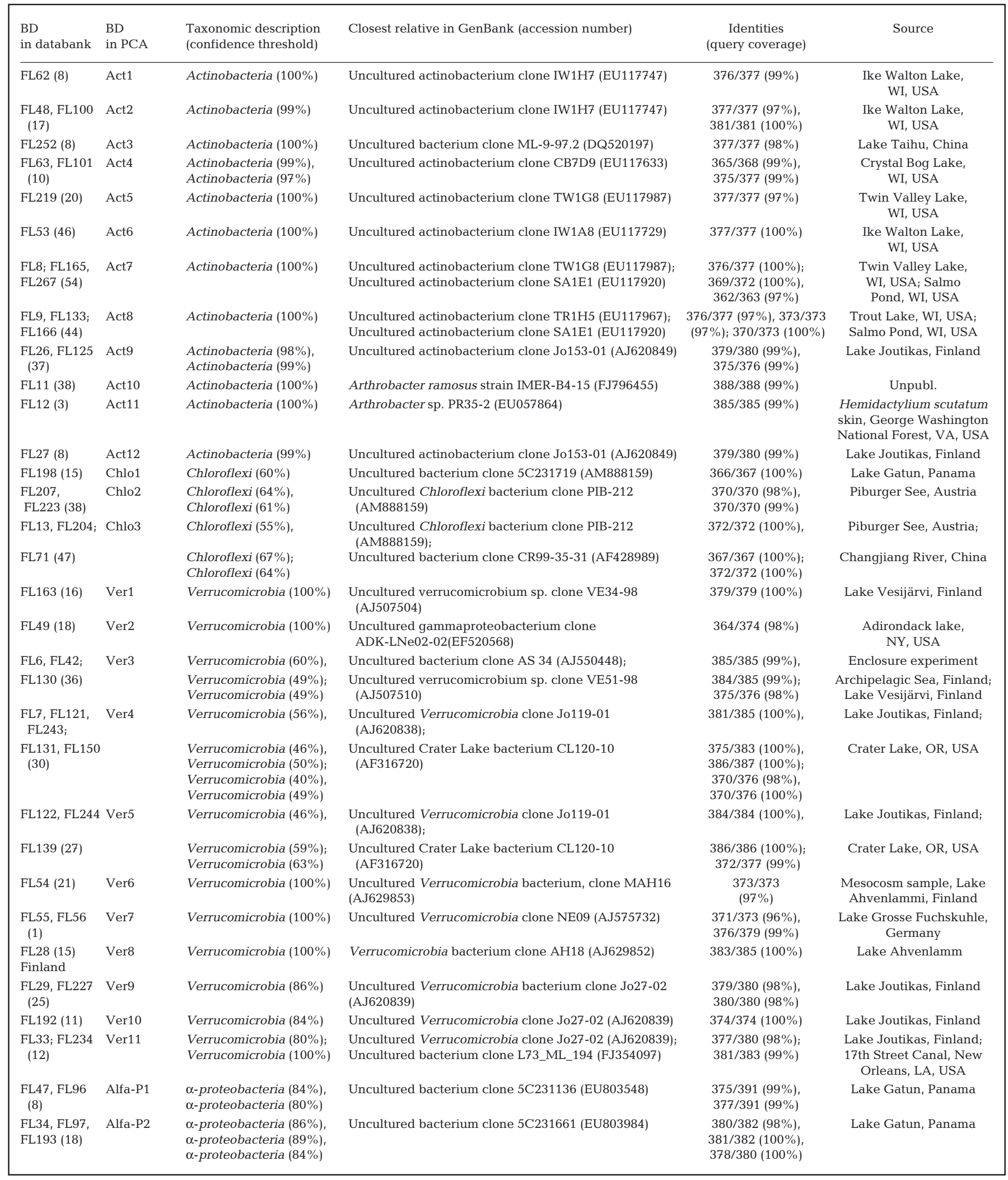


Table 1 (continued)

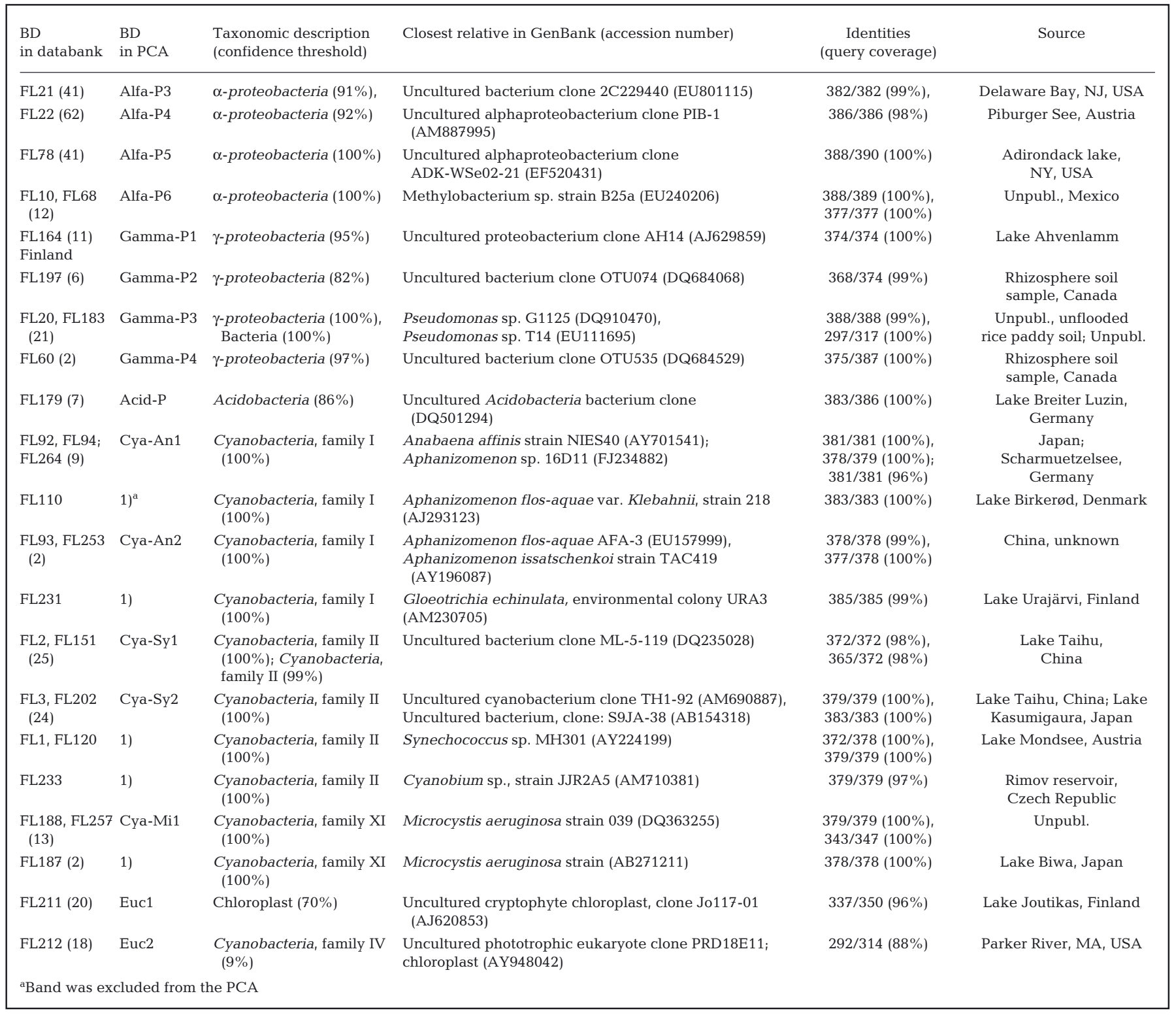

similar to uncultured actinobacterium sp. (clones TW1G8 and SA1E1) found in lakes in the USA. Sequences (FL13, FL71, FL204; Table 1) from the third most common band position observed in 47 lakes in Finland were very similar to Chloroflexi sequences obtained from the Piburger See in Austria and the Changjiang River in China. Four other bands were observed in DGGE analyses of samples from more than 40 lakes. Sequences (FL53, FL9, FL133, FL166; Table 1) derived from 2 of these bands were related to those of Actinobacteria; sequences (FL21, FL78; Table 1) from the other 2 were related to those of Alphaproteobacteria and the closest relatives were found in each case in freshwater environments.

\section{Differences in bacterioplankton community composition in PCA}

In PCA, DGGE banding patterns clustered mainly according to the trophic status (TP concentration) of the lakes (Fig. 1). The first principal component of PCA explained $42 \%$ and the second axis $33 \%$ of the variation. Sequenced DGGE bands, which are indicated with arrows in the PCA plot (Fig. 1), showed that certain bacterial phylotypes were typical of a specific trophic level. Most of the oligotrophic and mesotrophic lakes are placed on the right side and bottom of the plot (Fig. 1). A few of the oligo- and mesotrophic lakes are placed at top of the plot 


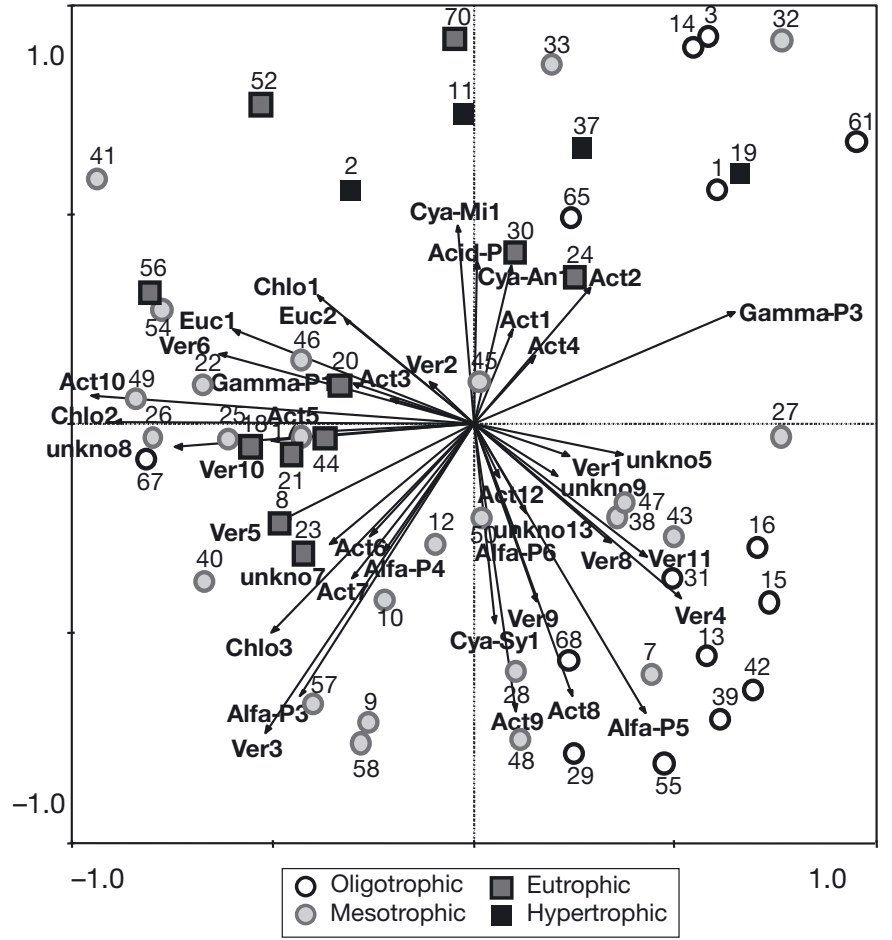

Fig. 1. Principal component analysis (PCA) plot showing clustering of the DGGE fingerprint patterns obtained from 55 Finnish lakes. Arrows indicate DGGE bands. Abbreviation 'unkno' indicates those DGGE bands that could not be sequenced; other abbreviations are as in Table 1. Total phosphorus concentration in oligotrophic lakes was $<10 \mathrm{mg} \mathrm{l}^{-1}(\mathrm{O})$; in mesotrophic lakes, 10 to $34 \mathrm{mg} \mathrm{l}^{-1}(\mathrm{O})$; in eutrophic lakes, 35 to $100 \mathrm{mg} \mathrm{l}^{-1}(\square)$; and in hypertrophic lakes, $>100 \mathrm{mg} \mathrm{l}^{-1}$ (匹). Numbers refer to the lakes (see Table S1 in the supplement)

because of their divergent DGGE profiles. The majority of the DGGE profiles from the eutrophic as well as mesotrophic lakes with near eutrophic phosphorus levels are placed on the left side and in the middle of the plot (Fig. 1). All 4 hypertrophic lakes are placed at the top of the PCA plot (Fig. 1) due to their similar DGGE profiles.

\section{Canonical correspondence analysis}

In the CCA plot, lakes grouped according to the trophic status based on TP (Fig. 2). Of the environmental variables used, TP and chl a autocorrelated strongly ( $\mathrm{r}=0.86$; see Table 3$)$. In the CCA model, only 2 variables were statistically significantly $(\mathrm{p}<0.05)$ related to the bacterioplankton community composition at a time: one of the autocorrelating variables (chl a or TP) and the DIN:DIP ratio (Fig. 2). For the final CCA model, chl a was chosen as a more general biological variable that includes the effect of TP. In the CCA clustering of the lake samples, chl a has the most pronounced effect; samples from the oligotrophic and mesotrophic lakes are placed to one side, and the samples from the eutrophic and hypertrophic lakes are placed on the other side together with the chl a vector (Fig. 2A). The same clustering was found when TP was used instead of chl $a$ in the model (Fig. 2B). According to the CCA, species and significant environmental variables based on the 2 ordination axes explained $19 \%$ of the taxonomic variation of the bacterioplankton in the 55 samples included in the analysis (Table 2).

$\mathrm{Chl} a$, the factor that was related to bacterial community composition, had a statistically significant positive correlation to TP, TN and water colour, and negative correlation to Secchi depth and TN:TP ratio (Table 3). Thus, higher TP and TN, darker water colour, lower transparency and lower TN:TP ratio associated with bacterial communities of eutrophic and hypertrophic lakes. The DIN:DIP ratio was significantly and positively correlated to $\mathrm{N}\left(\mathrm{NO}_{3}-\mathrm{NO}_{2}\right)$ and the TN:TP ratio (Table 3).

\section{DISCUSSION}

Results of the CCA of bacterioplankton community DGGE profiles and environmental parameters as explanatory factors indicated that phytoplankton biomass, as detected by chl a or TP, and the DIN:DIP ratio were significantly related to the bacterial community composition. The importance of phytoplankton to the BCC has been shown earlier in many other studies (e.g. Horner-Devine et al. 2003, Jardillier et al. 2004, Yannarell \& Triplett 2004, Kritzberg et al. 2006), whereas the DIN:DIP ratio has been found to be more

Table 2. Summary of canonical correspondence analysis (CCA) of the bacterioplankton community composition data obtained from 55 lake samples

\begin{tabular}{|lcc|}
\hline Parameter & $\begin{array}{c}\text { Axis 1 } \\
\text { (chl a) }\end{array}$ & $\begin{array}{c}\text { Axis 2 } \\
\text { (DIN:DIP) }\end{array}$ \\
\hline Number of samples (lakes) & 55 & \\
Number of species (DGGE band positions) ${ }^{\mathrm{a}}$ & 49 & \\
Eigenvalues & 0.144 & 0.046 \\
Species-environment correlations & 0.863 & 0.725 \\
Cumulative percentage variance of species data & 7.6 & 10.0 \\
Cumulative percentage variance of species- & 76.0 & 100.0 \\
environment relation & 0.190 & \\
Sum of all canonical eigenvalues & & \\
a'Rare bands (12 out of 61) were excluded from the CCA & \\
& & \\
\hline
\end{tabular}



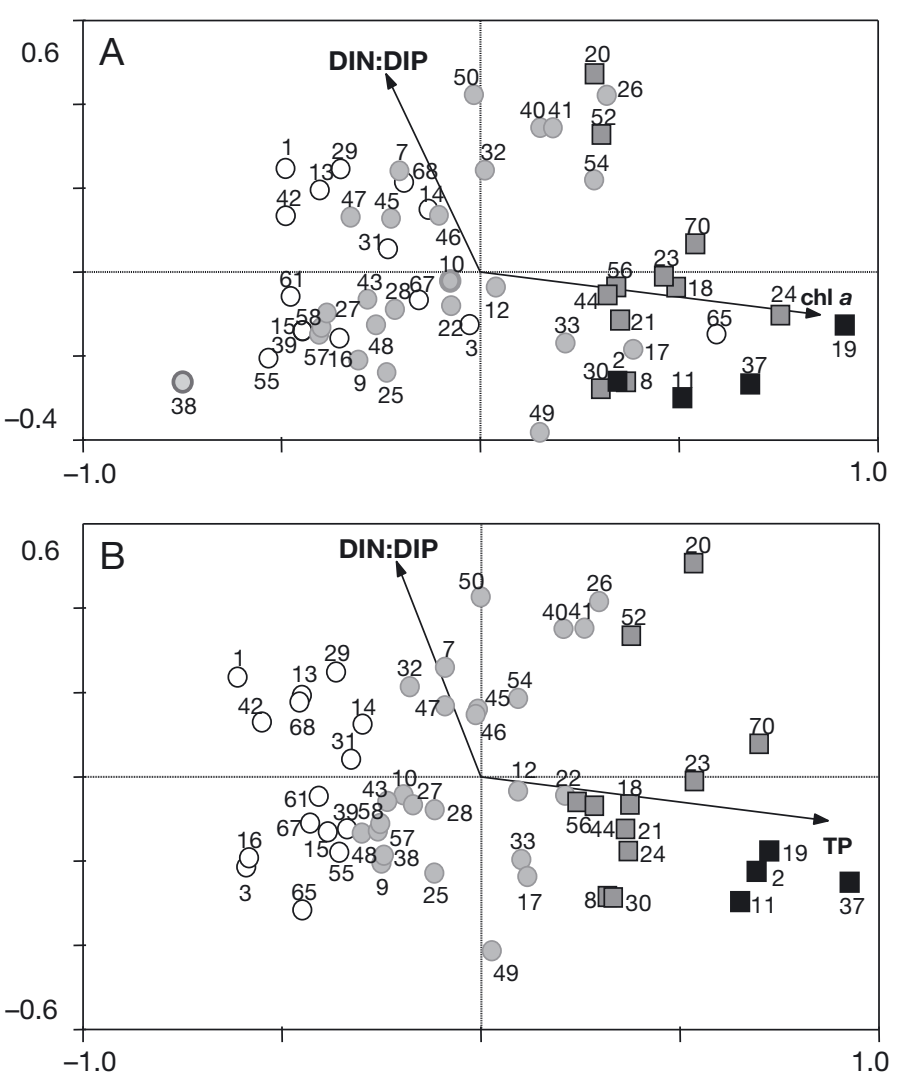

Fig. 2. Canonical correspondence analysis (CCA) biplot showing bacterial community composition in relation to the 2 strongest environmental variables: ratio of dissolved inorganic nitrogen to dissolved inorganic phosphorus (DIN:DIP), and (A) chlorophyll a (chl a) or (B) total phosphorus (TP). TP concentration in oligotrophic lakes was $<10 \mathrm{mg} \mathrm{l}^{-1}(\mathrm{O})$; in mesotrophic lakes, 10 to $34 \mathrm{mg} \mathrm{l}^{-1}(0)$; in eutrophic lakes, 35 to $100 \mathrm{mg} \mathrm{l}^{-1}(\square)$; and in hypertrophic lakes, $>100 \mathrm{mg} \mathrm{l}^{-1}(\mathbf{\square})$. Numbers refer to the lakes (see Table S1 in the supplement)

relevant in determining the cyanobacterial community (Hyenstrand et al. 1998). In the CCA plot, the low DIN:DIP ratio correlated with a high chl a concentration and thus with high levels of phytoplankton. In addition, total concentrations of both nutrients ( $\mathrm{P}$ and $\mathrm{N})$ as well as water colour were positively correlated with chl a (Table 3). Thus, many environmental variables that are known to be related to trophic status were found to be associated with the $\mathrm{BCC}$ of the Finnish lakes studied.

Phosphorus and nitrogen often limit the growth of both bacterio- and phytoplankton (Wetzel 1983, Fisher et al. 2000, Vrede 2005), and enrichment of these nutrients in lakes can also influence BCC (Fisher et al. 2000, Haukka et al. 2006). High concentrations of TP have been shown to increase the cyanobacterial and phytoplankton biomass and thus also the concentration of chl a (Watson et al. 1997). Previously, in the study by
Rantala et al. (2006), it was found that higher $\mathrm{pH}$ and TN concentration as well as a larger surface area of the lake increased the occurrence probability of potentially hepatotoxic cyanobacteria in the lakes used in the present study. Analyses of large lake data sets from Europe found TN concentrations to be among the important factors contributing to overall BCC patterns together with other factors associated with densities/ biomass of grazers, lake depth and $\mathrm{pH}$ as well as drainage area parameters (Van der Gucht et al. 2007). In our CCAs, $19 \%$ of the variation was explained by significant environmental parameters. This corresponds closely to the proportion of variation found to be explained by environmental factors in the BCC of other large data sets (Van der Gucht et al. 2007).

Similar to the present investigation, several studies have found the dominant forces structuring $\mathrm{BCC}$ to be primary productivity (measured as concentration of chl a) and dissolved organic carbon (DOC) (Crump et al. 2003, Horner-Devine et al. 2003, Stepanauskas et al. 2003, Jardillier et al. 2004, Yannarell \& Triplett 2004, Kritzberg et al. 2006). It is well established that strong seasonal changes in BCC occur (e.g. Yannarell et al. 2003, Shade et al. 2007, 2008, Nelson 2009). In our study, the samples originated from 67 lakes, but were mainly taken during the middle of summer before the cyanobacterial bloom-forming season.

Sequence analysis of DGGE bands revealed the presence of Verrucomicrobia-, Actinobacteria-, Cyanobacteria-, Alpha- and Gammaproteobacteria-, Chloroflexi- and Acidobacteria-related phylotypes in the lakes studied. All these bacterial phyla are frequently found in freshwater environments (Table 1). Database analysis of 16S rRNA gene sequences from freshwater by Zwart et al. (2002) showed that a relatively small number of bacterial phyla dominates the freshwater plankton. Our results confirm that this is

Table 3. Correlation coefficients of environmental variables with variables used in the CCA model. Statistically significant correlations $(p<0.05)$ are marked in bold

\begin{tabular}{|lcr|}
\hline Environmental variable & Chl $a$ & DIN:DIP \\
\hline Chl a & 1.0 & -0.466 \\
Secchi depth & $\mathbf{- 0 . 8 0 4}$ & 0.322 \\
Temperature & 0.189 & -0.274 \\
Total phosphorus (TP) & $\mathbf{0 . 8 6 2}$ & -0.430 \\
Total nitrogen (TN) & $\mathbf{0 . 7 9 2}$ & 0.011 \\
TN:TP & $\mathbf{- 0 . 6 2 7}$ & $\mathbf{0 . 6 0 9}$ \\
pH & 0.573 & -0.317 \\
Water colour & $\mathbf{0 . 6 3 1}$ & -0.056 \\
N(NO NO $_{2}$ ) & -0.095 & $\mathbf{0 . 8 6 1}$ \\
DIN:DIP & -0.466 & 1.0 \\
Latitude & -0.218 & 0.044 \\
Longitude & -0.264 & 0.274 \\
\hline
\end{tabular}


also the case in the Finnish boreal lakes studied. According to Zwart et al. (2002), the major bacterial divisions present in most freshwaters are Alpha- and Betaproteobacteria, Cytophaga-Flavobacterium-Bacteroides (CFB), Actinobacteria and Verrucomicrobia. Other studies have shown that Actinobacteria, Betaproteobacteria and CFB are the most numerous phylogenetic groups in freshwater clone libraries (Glöckner et al. 2000, Stepanauskas et al. 2003, Zwisler et al. 2003, Eiler \& Bertilsson 2004). Betaproteobacteria or $\mathrm{CFB}$ were not detected in the present study. However, these groups might have been present, since we did not succeed in sequencing bands from every position in the DGGE gels. In addition, DGGE is known to detect the most abundant bacterial phylotypes (Ferris \& Ward 1997). PCR amplification can distort the results, and the choice of the primer set can have an effect on the DGGE analysis. The F-968 primer used in the present study included an internal mismatch to many freshwater betaproteobacterial sequences, which could have lowered their detection frequency. However, in our earlier work (Kolmonen et al. 2004, Haukka et al. 2006), Betaproteobacteria and CFB were detected sporadically from the lake samples using DGGE with the same primer set.

The majority of the DGGE band-derived sequences were related to Verrucomicrobia. The study also indicated that there were verrucomicrobial phylotypes that preferred oligo-mesotrophic conditions, whereas the other phylotypes were frequent in eutrophic lakes (Fig. 1). In our earlier study of the bacterioplankton community in lake mesocosms (Haukka et al. 2006), Verrucomicrobia correlated with more eutrophic conditions and Actinobacteria with less eutrophic conditions. In addition, our previous studies on BCC, conducted in just a few lakes, indicated that Verrucomicrobia are more prevalent in eutrophic lakes than in oligo- or mesotrophic lakes (Kolmonen et al. 2004, Haukka et al. 2005). The present extensive analysis of 67 lakes indicates that studies of individual lakes may not reveal general trends in how environmental factors affect BCC. Our results are in agreement with the mesocosm study by Sipura et al. (2005) in the Baltic Sea Archipelago, where Verrucomicrobia were most frequent in control mesocosms, whereas nutrient additions decreased the DGGE band intensities.

Actinobacteria-related sequences were frequently retrieved from the lake samples. Previous studies have shown Actinobacteria to be a common and important component of the freshwater bacterioplankton (Glöckner et al. 2000, Urbach et al. 2001, Warnecke et al. 2005). Recently, strains of aquatic Actinobacteria have been isolated from oligotrophic to hypereutrophic lakes (Hahn et al. 2003). It has been suggested that some Actinobacteria are possibly common in the bacterioplankton because they are very small in size and resist predation by protists (Pernthaler et al. 2001, Hahn et al. 2003, Warnecke et al. 2004). In the present study, some Actinobacteria (e.g. Act 1, 2, 4; Fig. 1) were associated with eutrophic lakes, indicating that certain phylotypes of this group may be important degraders of phytoplankton biomass. On the other hand, other Actinobacteria-related phylotypes (Act 6 to 8 ) were found associated with less eutrophic lakes, suggesting an important role for this phylum in mid-summer bacterioplankton communities in Finnish lakes. Previously, Lindström \& Leskinen (2002) found that lakes in Swedish Lapland (bog lakes) commonly contain Actinobacteria, whereas our samples all came from lakes in southern and central Finland.

Cyanobacteria occurred most commonly in hypereutrophic lakes, according to the DGGE results. In the oligo- and mesotrophic lakes, the picocyanobacterial genera were detected, while the bloom-forming genera, Anabaena and Microcystis, were more often present in the eutrophic and hypertrophic lakes. In previous studies using the same environmental data set, potential cyanobacterial hepatotoxin (microcystin) producers, Anabaena, Microcystis and Planktothrix, were detected in approximately $90 \%$ of the lakes by PCR (Rantala et al. 2006) and the cyanobacterial genera Snowella and Woronichinia were commonly found through microscopy in the oligo- and mesotrophic lakes (Rajaniemi-Wacklin et al. 2006). In the present study, cyanobacterial genera were detected less frequently using DGGE with the eubacterial primer set. The primer R-1401 had a mismatch for most of the cyanobacterial sequences in the RDP Database, most probably causing the lower detection frequency. Our earlier study demonstrated that it is preferable to use cyanobacteria-specific primers in DGGE and cloning when targeting the cyanobacterial community (Rajaniemi-Wacklin et al. 2008).

In the present study, Alphaproteobacteria sequences were encountered more frequently than Gammaproteobacteria. An Alphaproteobacteria-related sequence was retrieved from a band (FL22) located in the most prominent band position that was present in 62 of the 67 lakes investigated (Table 1), suggesting that certain members of this phylum are common in Finnish lakes. Alphaproteobacteria were found dominating in the mesotrophic Biwa Lake throughout the season (Nishimura \& Nagata 2007). In the northern boreal lakes, Alpha- and Betaproteobacteria were dominant classes in the clone libraries of 3 eutrophic Swedish lakes during the cyanobacterial bloom (Eiler \& Bertilsson 2004). In Swedish lakes, Alphaproteobacteria appeared to be more common in lakes with neutral to alkaline $\mathrm{pH}$, in contrast to more acidic waters (Lind- 
ström \& Leskinen 2002). Similar to the present study, Lindström et al. (2005) also found Gammaproteobacteria to occur only rarely in 15 studied lakes in northern Europe. Betaproteobacteria are common in freshwater lakes (e.g. Zwart et al. 2002) and are probably capable of degrading complex organic macromolecules (Kirchman 2002), but this group and Deltaproteobacteria were not detected in our study.

Through DGGE analysis, we found that certain band positions, some with sequences related to Alphaproteobacteria and Actinobacteria, were common in all lakes despite differences in the trophic status or water chemistry of the lake. Similarly, many previous studies have found certain strains or bacterioplankton phylotypes to be common regardless of the various environmental gradients or regions (Hahn et al. 2003, Lindström et al. 2005, Van der Gucht et al. 2007). Similar phylotypes (based on the 16S rRNA gene sequence) may, however, represent various ecotypes differing in their environmental requirements, as was recently shown with isolates of Actinobacteria (Hahn \& Pöckl 2005). Genome projects of various strains of the same organisms have shown that ribosomal genes belong to the core genes of the organisms and may not reflect the enormous niche adaptation gene pool contained in the individual strains (Medini et al. 2005). Our extensive analysis of the BCC in Finnish lakes showed that trophic status is an important factor in shaping the bacterioplankton communities, reflected in changes at the phyla level as well as in individual phylotypes. In future, next generation sequencing technologies are likely to reveal detailed information about bacterioplankton community composition as well as niche adaptation of individual organisms.

Acknowledgements. This study was financially supported by grants from the Academy of Finland (grants 118637, 214457) to K.S. and (128480) to A.R.-Y., the EU project MIDI-CHIP (EVK2-CT-1999-00026) to K.S., and the Finnish Graduate School in Environmental Science and Technology (EnSTe) to E.K.

\section{LITERATURE CITED}

Altschul SF, Madden TL, Schaffer AA, Zhang J, Zhang Z, Miller W, Lipman DJ (1997) Gapped BLAST and PSIBLAST: a new generation of protein database search programs. Nucleic Acids Res 25:3389-3402

Crump BC, Kling GW, Bahr M, Hobbie JE (2003) Bacterioplankton community shifts in an arctic lake correlate with seasonal changes in organic matter source. Appl Environ Microbiol 69:2253-2268

Eiler A, Bertilsson S (2004) Composition of freshwater bacterial communities associated with cyanobacterial blooms in four Swedish lakes. Environ Microbiol 6:1228-1243

> Ferris MJ, Ward DM (1997) Seasonal distributions of dominant 16S rRNA-defined populations in a hot spring microbial mat examined by denaturing gradient gel electrophoresis. Appl Environ Microbiol 63:1375-1381
Fisher MM, Klug JL, Lauster G, Newton M, Triplett EW (2000) Effects of resources and trophic interactions on freshwater bacterioplankton diversity. Microb Ecol 40:125-138

Glöckner FO, Zaichikov E, Belkova N, Denissova L, Pernthaler J, Pernthaler A, Amann R (2000) Comparative 16S rRNA analysis of lake bacterioplankton reveals globally distributed phylogenetic clusters including an abundant group of Actinobacteria. Appl Environ Microbiol 66: 5053-5065

Hahn MW, Höfle MG (2001) Grazing of protozoa and its effect on populations of aquatic bacteria. FEMS Microbiol Ecol 35:113-121

Hahn MW, Pöckl M (2005) Ecotypes of planktonic Actinobacteria with identical 16S rRNA genes adapted to thermal niches in temperate, subtropical, and tropical freshwater habitats. Appl Environ Microbiol 71:766-773

Hahn MW, Lunsdorf $H, W u$ Q, Schauer M, Hofle MG, Boenigk J, Stadler P (2003) Isolation of novel ultramicrobacteria classified as Actinobacteria from five freshwater habitats in Europe and Asia. Appl Environ Microbiol 69:1442-1451

Haukka K, Heikkinen E, Kairesalo T, Karjalainen H, Sivonen K (2005) Effect of humic material on the bacterioplankton community composition in boreal lakes and mesocosms. Environ Microbiol 7:620-630

Haukka K, Kolmonen E, Hyder R, Hietala J and others (2006) Effect of nutrient loading on bacterioplankton community composition in lake mesocosms. Microb Ecol 51:137-146

Horner-Devine MC, Leibold MA, Smith VH, Bohannan BJM (2003) Bacterial diversity patterns along a gradient of primary productivity. Ecol Lett 6:613-622

Hyenstrand P, Blomqvist P, Pettersson A (1998) Factors determining cyanobacterial success in aquatic systems - a literature review. Arch Hydrobiol 51:41-62

Jardillier L, Basset M, Domaizon I, Belan A, Amblard C, Richardot M, Debroas D (2004) Bottom-up and top-down control of bacterial community composition in the eutrophic zone of a reservoir. Aquat Microb Ecol 35: 259-273

Jürgens K, Matz C (2002) Predation as a shaping force for the phenotypic and genotypic composition of planktonic bacteria. Ant Leeuwenhoek 81:413-434

- Kent AD, Jones SE, Yannarell AC, Graham JM, Lauster GH, Kratz TK, Triplett EW (2004) Annual patterns in bacterioplankton community variability in a humic lake. Microb Ecol 48:550-560

> Kirchman DL (2002) The ecology of Cytophaga-Flavobacteria in aquatic environments. FEMS Microbiol Ecol 39:91-100

Kolmonen E, Sivonen K, Rapala J, Haukka K (2004) Diversity of cyanobacteria and heterotrophic bacteria in cyanobacterial blooms in Lake Joutikas, Finland. Aquat Microb Ecol 36:201-211

Kritzberg ES, Langenheder S, Lindström ES (2006) Influence of dissolved organic matter source on lake bacterioplankton structure and function-implications for seasonal dynamics of community composition. FEMS Microbiol Ecol 56:406-417

Lindström ES (2000) Bacterioplankton community composition in five lakes differing in trophic status and humic content. Microb Ecol 40:104-113

> Lindström ES (2001) Investigating influential factors on bacterioplankton community composition: results from a field study of five mesotrophic lakes. Microb Ecol 42:598-605

> Lindström ES, Leskinen E (2002) Do neighboring lakes share common taxa of bacterioplankton? Comparison of $16 \mathrm{~S}$ rDNA fingerprints and sequences from three geographic regions. Microb Ecol 44:1-9 
Lindström ES, Kamst-Van Agterveld MP, Zwart G (2005) Distribution of typical freshwater bacterial groups is associated with $\mathrm{pH}$, temperature, and lake water retention time. Appl Environ Microbiol 71:8201-8206

- Medini D, Donati C, Tettelin H, Masignani V, Rappuoli R (2005) The microbial pan-genome. Curr Opin Genet Dev 15:589-594

Methé BA, Zehr JP (1999) Diversity of bacterial communities in Adirondack lakes: Do species assemblages reflect lake water chemistry? Hydrobiologia 401:77-96

Muylaert K, Van Der Gucht K, Vloemans N, Meester LD, Gillis M, Vyverman W (2002) Relationship between bacterial community composition and bottom-up versus topdown variables in four eutrophic shallow lakes. Appl Environ Microbiol 68:4740-4750

> Nelson CE (2009) Phenology of high-elevation pelagic bacteria: the roles of meteorologic variability, catchment inputs and thermal stratification in structuring communities. ISME J 3:13-30

Nishimura Y, Nagata T (2007) Alphaproteobacterial dominance in a large mesotprophic lake (Lake Biwa, Japan). Aquat Microb Ecol 48:231-240

Nübel U, Engelen B, Felske A, Snaidr J and others (1996) Sequence heterogeneities of genes encoding 16S rRNAs in Paenibacillus polymyxa detected by temperature gradient gel electrophoresis. J Bacteriol 178:5636-5643

Pernthaler J, Posch T, Simek K, Vrba J and others (2001) Predator-specific enrichment of Actinobacteria from a cosmopolitan freshwater clade in mixed continuous culture. Appl Environ Microbiol 67:2145-2155

Rajaniemi-Wacklin P, Rantala A, Mugnai MA, Turicchia S and others (2006) Correspondence between phylogeny and morphology of Snowella spp. and Woronichinia naegeliana, cyanobacteria commonly occurring in lakes. J Phycol 42:226-232

Rajaniemi-Wacklin P, Rantala A, Kuuppo P, Haukka K, Sivonen K (2008) Cyanobacterial community composition in shallow, eutrophic Lake Tuusulanjärvi studied by microscopy, strain isolation, DGGE and cloning. Algol Stud 126:137-157

Rantala A, Rajaniemi-Wacklin P, Lyra C, Lepistö L, Rintala J, Mankiewicz-Boczek J, Sivonen K (2006) Detection of microcystin-producing cyanobacteria in Finnish lakes with genus-specific microcystin synthetase gene E (mcyE) PCR and associations with environmental factors. Appl Environ Microbiol 72:6101-6110

Schauer M, Kamenik C, Hahn MW (2005) Ecological differentiation within a cosmopolitan group of planktonic freshwater bacteria (SOL cluster, Saprospiraceae, Bacteroidetes). Appl Environ Microbiol 71:5900-5907

Shade A, Kent AD, Jones SE, Newton RJ, Triplett EW, McMahon KD (2007) Interannual dynamics and phenology of bacterial communities in a eutrophic lake. Limnol Oceanogr 52:487-494

Shade A, Jones SE, McMahon KD (2008) The influence of habitat heterogeneity on freshwater bacterial community composition and dynamics. Environ Microbiol 10:1057-1067

Sipura J, Haukka K, Helminen H, Lagus A, Suomela J, Sivonen K (2005) Effect of nutrient enrichment on bacterioplankton biomass and community composition in mesocosms in the Archipelago Sea, northern Baltic. J Plankton Res 27:1261-1272

Editorial responsibility: Dittmar Hahn, San Marcos, Texas, USA
Stepanauskas R, Moran MA, Bergamaschi BA, Hollibaugh JT (2003) Covariance of bacterioplankton composition and environmental variables in a temperate delta system. Aquat Microb Ecol 31:85-98

ter Braak CJF, Smilauer P (2002) CANOCO reference manual and CanoDraw for Windows user's guide: software for canonical community ordination (version 4.5). Microcomputer Power, Ithaca, NY

Urbach E, Vergin KL, Young L, Morse A (2001) Unusual bacterioplankton community structure in ultra-oligotrophic Crater Lake. Limnol Oceanogr 46:557-572

Van der Gucht K, Sabbe K, De Meester L, Vloemans N, Zwart G, Gillis M, Vyverman W (2001) Contrasting bacterioplankton community composition and seasonal dynamics in two neighbouring hypertrophic freshwater lakes. Environ Microbiol 3:680-690

Van der Gucht K, Vandekerckhove T, Vloemans N, Cousin S and others (2005) Characterization of bacterial communities in four freshwater lakes differing in nutrient load and food web structure. FEMS Microbiol Ecol 53:205-220

- Van der Gucht K, Cottenie K, Muylaert K, Vloemans N and others (2007) The power of species sorting: local factors drive bacterial community composition over a wide range of spatial scales. Proc Natl Acad Sci USA 104:20404-20409

- Vrede K (2005) Nutrient and temperature limitation of bacterioplankton growth in temperate lakes. Microb Ecol 49: $245-256$

Wang Q, Garrity GM, Tiedje JM, Cole JR (2007) Naïve Bayesian classifier for rapid assignment of rRNA sequences into the new bacterial taxonomy. Appl Environ Microbiol 73:5261-5267

- Warnecke F, Amann R, Pernthaler J (2004) Actinobacterial 16S rRNA genes from freshwater habitats cluster in four distinct lineages. Environ Microbiol 6:242-253

Warnecke F, Sommaruga R, Sekar R, Hofer JS, Pernthaler J (2005) Abundances, identity, and growth state of Actinobacteria in mountain lakes of different UV transparency. Appl Environ Microbiol 71:5551-5559

> Watson SB, McCauley E, Downing JA (1997) Patterns in phytoplankton taxonomic composition across temperate lakes of differing nutrient status. Limnol Oceanogr 42: 487-495

Wetzel RG (1983) Limnology. Saunders College Publishing, Orlando, FL

> Yannarell AC, Triplett EW (2004) Within- and between-lake variability in the composition of bacterioplankton communities: investigations using multiple spatial scales. Appl Environ Microbiol 70:214-223

Yannarell AC, Triplett EW (2005) Geographic and environmental sources of variation in lake bacterial community composition. Appl Environ Microbiol 71:227-239

Yannarell AC, Kent AD, Lauster GH, Kratz TK, Triplett EW (2003) Temporal patterns in bacterial communities in three temperate lakes of different trophic status. Microb Ecol 46:391-405

Zwart G, Crump BC, Kamst-van Agterveld MP, Hagen F, Han S (2002) Typical freshwater bacteria: an analysis of available 16S rRNA gene sequences from plankton of lakes and rivers. Aquat Microb Ecol 28:141-155

Zwisler W, Selje N, Simon M (2003) Seasonal patterns of the bacterioplankton community composition in a large mesotrophic lake. Aquat Microb Ecol 31:211-225

Submitted: April 30, 2009; Accepted: September 27, 2010

Proofs received from author(s): January 19, 2011 